\title{
DESKRIPSI PENERAPAN PATIENT SAFETY PADA PASIEN DI BANGSAL BEDAH
}

\author{
Imelda Rahmayunia Kartika ${ }^{1}$ \& Yelpio Stenalia ${ }^{2}$ \\ ${ }^{1}$ Dosen Keperawatan STIKes Fort De Kock Bukittinggi \\ ${ }^{2}$ Mahasiswa Keperawatan STIKes Fort De Kock Bukittinggi \\ imelda.rahmayunia@fdk.ac.id
}

Submitted: 03-07-2019, Reviewer: 03-07-2019, Accepted: 05-07-2019

\begin{abstract}
The hospital is one of the health care facilities that aims to maintain a better health. Patient safety is the main priority to be implemented in the Hospital and it is related to the quality of the Hospital. This study aims to determine the management of the application of patient safety in the surgical ward of RSUD DR. Achmad Mochtar Bukittinggi. This study uses a quantitative research design with a descriptive analytic approach with the aim of analyzing the results of patient perceptions about the management of the implementation of patient safety by nurses. Samples were taken using accidental sampling, with the inclusion criteria being patients who had been treated for at least 3 days in the room so that it was seen how nurses applied patient safety. Data analysis used was univariate analysis and bivariate analysis using chi-square test. The results showed that 104 respondents (62\%) said that with high patient safety management. Based on the results of the study it can be concluded that the application of patient safety by nurses in the operating room is best done in terms of giving consent sheets before performing surgery with a mean of 3.90 (range 4), where this is important as a form of informed consent for patients. It is expected that the hospital can consider the management of implementing patient safety as a reference so that nurses can work optimally.
\end{abstract}

Keywords: $\quad$ patient safety, management, surgical ward

\begin{abstract}
ABSTRAK
Rumah sakit merupakan salah satu sarana pelayanan kesehatan yang bertujuan untuk pemulihan dan pemeliharaan kesehatan yang lebih baik. Patient safety merupakan prioritas utama untuk dilaksanakan di Rumah Sakit dan hal itu terkait dengan isu mutu dan citra Rumah Sakit. Penelitian ini bertujuan untuk mengetahui penerapan patient safety di bangsal bedah RSUD DR. Achmad Mochtar Bukittinggi. Penelitian ini menggunakan desain penelitian kuantitatif dengan pendekatan deskriptif analitik dengan tujuan menganalisa hasil persepsi pasien tentang manajemen penerapan patient safety oleh perawat. Sampel sebesar 167 orang diambil menggunakan accidental sampling, dengan kriteria inklusi adalah pasien yang telah dirawat minimal 3 hari di ruangan agar terlihat bagaimana perawat menerapkan patient safety. Analisis data yang digunakan adalah analisis univariat dan analisis bivariate menggunakan uji chi-square. Hasil penelitian didapatkan 104 responden (62\%) mengatakan dengan manajemen patient safety tinggi. Berdasarkan hasil penelitian dapat disimpulkan bahwa penerapan patient safety oleh perawat di ruang bedah yang paling baik dilakukan adalah dalam hal memberikan lembar persetujuan sebelum melakukan tindakan operasi dengan mean 3,90 (range 4), dimana hal ini penting dilakukan sebagai bentuk inform concent bagi pasien. Diharapkan rumah sakit dapat mempertimbangkan manajemen penerapan patient safety sebagai rujukan sehingga perawat dapat bekerja secara optimal.
\end{abstract}

Kata kunci: patient safety, manajemen, bangsal bedah 


\section{PENDAHULUAN}

Keselamatan pasien pada suatu Rumah Sakit merupakan suatu keharusan yang harus dijalankan oleh setiap Rumah Sakit yang ada di Indonesia, karena hal ini telah di amanahkan oleh Undang-Undang No. 44/2009 tentang Rumah Sakit yaitu pasal 40 ayat (1) dalam upaya peningkatan mutu pelayanan Rumah Sakit wajb dilakukan akreditasi secara berkala minimal 3 (tiga) tahun sekali dan ayat (2) Akreditasi Rumah Sakit sebagai mana yang dimaksud pada ayat (1) dilakukan oleh suatu lembaga independen baik dari dalam maupun dari luar negeri berdasarkan akreditasi yang berlaku. Akreditasi Rumah Sakit merupakan salah satu persyaratan dalam pengurusan izin Operasional Rumah Sakit. Dalam persyaratan akreditasi salah satu sasaran yang menjadi perhatian sangat besar dalam mutu pelayanan adalah keselamatan pasien. Akreditasi Rumah Sakit adalah suatu pengakuan yang diberikan oleh pemerintah pada Rumah Sakit karena telah memenuhi standar yang telah ditentukan (DepKes RI, 2003).

Keselamatan pasien merupakan prioritas utama untuk dilaksanakan di Rumah Sakit dan hal itu terkait dengan isu mutu dan citra Rumah Sakit. Rumah Sakit menuju pengakuan internasional harus melalui proses akreditasi dilakukan oleh lembaga independen yang memiliki kewenangan untuk memberikan penilaian tentang kualitas pelayanan diinstitusi pelayanan kesehatan. Salah satu lembaga akreditas internasional Rumah Sakit yang telah diakui oleh dunia adalah Joint Commission International (JCI) (JCI, 2011 ; Arefa, 2015).

Keselamatan pasien merupakan isu global yang paling penting saat ini, dimana sekarang banyak dilaporkan tuntutan pasien atas medical error yang terjadi pada pasien. Keselamatan pasien rumah sakit adalah suatu sistem dimana rumah sakit membuat asuhan pasien lebih aman yang memiliki assesmen resiko, identifikasi dan pengelolaan hal yang berhubungan dengan resiko pasien, pelaporan dan analisis insiden, kemampuan belajar dari insiden dan tindak lanjut (KemenKes RI, 2011).

Keselamatan pasien (Patient Safety) merupakan suatu variabel untuk mengukur dan mengevaluasi kualitas pelayanan keperawatan yang berdampak terhadap pelayanan kesehatan. Sejak malpraktik menggema diseluruh belahan bumi melalui berbagai media baik cetak maupun elektronik hingga ke jurnal-jurnal ternama, dunia kesehatan mulai menaruh kepedulian yang tinggi terhadap isu keselamatan pasien (Nursalam, 2011).

Keselamatan pasien (Patient Safety) merupakan sesuatu yang jauh lebih penting dari pada sekedar efisiensi pelayanan. Perilaku perawat dengan kemampuan perawat sangat berperan penting dalam pelaksanaan keselamatan pasien. Perilaku yang tidak aman, lupa, kurangnya perhatian/ motivasi, kecerobohan, tidak teliti dan kemampuan yang tidak memperdulikan dan menjaga keselamatan pasien berisiko untuk terjadinya kesalahan dan akan mengakibatkan cedera pada pasien, berupa Near Miss (Kejadian Nyaris Cedera/ KNC) atau Adverse Event (Kejadian Tidak Diharapkan/ KTD) selanjutnya pengurangan kesalahan dapat dicapai dengan memodifikasi perilaku (WHO, 2014 ; Lombogia et al, 2016).

Perawat yang kompeten harus melibatkan kognitif, afektif dan tindakan yang mengutamakan keselamatan pasien (Kartika, Hariyati, \& Nelwati, 2018). Keselamatan pasien merupakan masalah 
kesehatan masyarakat global yang serius. Di Eropa pasien dengan resiko infeksi $83,5 \%$ dan bukti kesalahan medis menunjukkan 50-72,3\%. Di kumpulkan angka-angka penelitian rumah sakit di berbagai Negara, ditemukan KTD dengan rentang 3,2 - 16,6 \% (WHO, 2014; Lombogia et al, 2016). Data di Indonesia tentang KTD apalagi Kejadian Nyaris Cedera (Near Miss) masih langka, namun dilain pihak terjadi peningkatan tuduhan "mal praktek", yang belum tentu sesuai dengan pembuktian akhir. Insidensi pelanggaran patient safety $28.3 \%$ dilakukan oleh perawat. Perawat harus menyadari perannya sehingga harus dapat berpartisipasi aktif dalam mewujudkan Patient Safety. Kerja keras perawat tidak dapat mencapai level optimal jika tidak didukung dengan sarana prasarana, manajemen rumah sakit dan tenaga kesehatan lainnya (Bawelle, Sinolungan, \& Hamel, 2013)

Sumatera Barat sendiri saat ini masih sulit ditemukan kejadian cidera dikarenakan budaya pelaporan terhadap insiden keselamatan pasien oleh petugas kesehatan masih rendah. Namun pada tahun 2014 didapatkan data kejadian pasien jatuh disalah satu rumah sakit Sumatera Barat. Pada awal tahun 2013 juga terdapat kasus yang merenggut nyawa pasien yaitu kasus bayi bernama Dera yang meninggal karena ditolak oleh 8 rumah sakit rujukan yang ada di Jakarta dengan alasan penuhnya ruang Neonatal Intensif Care Unit (NICU). Tidak berselang lama juga terjadi kasus meninggalnya bayi bernama Upik yang dinyatakan lahir meninggal oleh petugas medis disuatu instansi pelayanan kesehatan kemudian bayi tersebut hidup kembali lalu meninggal selang beberapa waktu setelah dibawa kembali kerumah sakit yang berbeda (Mudayana, 2014)

Kejadian Tidak Diharapkan (KTD) yang sering terjadi pada pasien selama dirawat dapat disebabkan oleh berbagai faktor antara lain: lingkungan kerja, halhal yang berhubungan dengan kondisi pasien, alur komunikasi yang kurang tepat, penggunaan sarana kurang tepat, kebijakan dan prosedur yang tidak adekuat. Semua faktor tersebut menimbulkan terjadinya insiden keselamatan pasien yang beragam, mulai dari yang ringan dan sifatnya reversible hingga yang berat berupa kecacatan atau bahkan kematian (Iswati, 2013).

Salah satu tujuan dari keselamatan pasien adalah mengurangi angka insiden keselamatan pasien (IKP). Insiden keselamatan pasien adalah setiap kejadian yang tidak disengaja dan kondisi yang mengakibatkan cedera yang dapat dicegah pada pasien. IKP terdiri dari kejadian tidak diharapkan (KTD), kejadian nyaris cedera (KNC), kejadian tidak cedera (KTC), kejadian potensial cedera (KPC) dan sentinel (Gunawan, Widodo, \& Harijanto, 2015)

Berdasarkan hasil observasi yang dilakukan di ruang rawat inap bedah RSUD Dr. Achmad Mochtar Bukittinggi, didapatkan hasil observasi perawat belum melakukan tindakan sesuai dengan standar JCI. Dalam melakukan identifikasi pasien, perawat sudah melakukan identifikasi pasien dan memilah pasien, namun belum optimal dilaksanakan. Sedangkan dari segi komunikasi tampak efektif sesuai dengan standar JCI, ada komunikasi yang tepat, akurat dan efektif antara perawat, dokter dan pasien. Dalam pemberian obat-obatan sudah dilakukan sesuai dengan SOP di ruangan sesuai dengan JCI. 
Pemberian tindakan pembedahan sudah dilakukan sesuai standar JCI. Dalam pengurangan resiko infeksi belum sesuai dengan standar JCI seperti pada saat melakukan tindakan perawat tidak menggunakan handscoon (sarung tangan) dan membiarkan luka terbuka lama. Dan pengurangan resiko pasien jatuh belum sepenuhnya dilakukan. Ini ditandai dengan tidak semua pasien dipasang pengaman pada brankar. Dari data diatas, peneliti tertarik melihat bagaimana manajemen penerapan patient safety di ruang bedah RSAM Bukittinggi.

\section{METODE PENELITIAN}

\section{Desain penelitian}

Penelitian ini menggunakan desain penelitian kuantitatif dengan pendekatan deskriptif analitik dengan tujuan menganalisa hasil persepsi pasien tentang manajemen penerapan patient safety oleh perawat.

\section{Sampel penelitian}

Sampel penelitian ini adalah 167 responden di ruang rawat inap bedah RSUD Dr. Achmad Mochtar Bukittinggi. Sampel diambil menggunakan accidental sampling, dengan kriteria inklusi adalah pasien yang telah dirawat minimal 3 hari di ruangan agar terlihat bagaimana perawat menerapkan patient safety.

\section{Instrumen penelitian}

Instrumen yang digunakan adalah kuesioner tentang penerapan manajemen patient safety berisi 15 item pernyataan positif menggunakan skala likert dengan sering dinilai 4, kadang-kadang dinilai 3, jarang dinilai 2, dan tidak pernah dinilai 1 . Sedangkan pernyataan negatif sering dinilai 1, kadang-kadang dinilai 2, jarang dinilai 3, dan tidak pernah dinilai 4 .

\section{Analisa data}

Analisa data yang digunakan adalah deskriptif frekuensi untuk melihat gambaran variabel manajemen penerapan patient safety yang dilakukan oleh perawat.

\section{HASIL PENELITIAN}

Analisa univariat dilakukan untuk menggambarkan karakteristik variabel penelitian yang akan disajikan dalam bentuk tabel distribusi frekuensi. Pada penelitian ini analisa univariat akan menggambarkan perawat dalam penerapan manajemen patient safety di ruang rawat inap bedah RSUD Dr. Achmad Mochtar Bukittinggi tahun 2018.

Berdasarkan tabel distribusi frekuensi 1 dapat diketahui bahwa dari 167 responden, tercatat 104 responden (62\%) dengan manajemen patient safety tinggi.

Berdasarkan tabel 2, dapat disimpulkan bahwa penerapan patient safety oleh perawat di ruang bedah yang paling baik dilakukan adalah dalam hal memberikan lembar persetujuan sebelum melakukan tindakan operasi dengan mean 3,90 (range 4) dimana hal ini penting dilakukan sebagai bentuk inform concent bagi pasien.

Tabel 1

Distribusi Frekuensi Kategori Penerapan Manajemen Patient Safety

\begin{tabular}{|c|c|c|c|}
\hline No & Patient safety & $\mathbf{f}$ & $\%$ \\
\hline 1 & Baik & 104 & 62 \\
\hline 2 & Kurang Baik & 63 & 38 \\
\hline
\end{tabular}




\begin{tabular}{ccc}
\hline Jumlah & 167 & 100 \\
\hline
\end{tabular}

Tabel 2

Distribusi frekuensi berdasarkan kuesioner penerapan manajemen patient safety yang dinilai oleh pasien di Ruang Rawat Inanp Bedah RSUD Achmad Mochtar Bukittinggi

\begin{tabular}{|c|c|c|c|c|}
\hline \multicolumn{2}{|c|}{ Variable } & $a$ & Mean & \multirow[t]{2}{*}{$S D$} \\
\hline \multicolumn{4}{|c|}{ Manajemen penerapan pasien safety } & \\
\hline \multicolumn{5}{|c|}{ a. Ketepatan Identifikasi Pasien } \\
\hline & 1. Perawat memperkenalkan namanya & 16 & 2,42 & 1,291 \\
\hline 2. & $\begin{array}{l}\text { 2. Perawat mengidentifikasi gelang sebelum } \\
\text { melakukan tindakan }\end{array}$ & 13 & 3,31 & 0,871 \\
\hline \multicolumn{5}{|c|}{ b. Peningkatan Komunikasi yang Efektif } \\
\hline 3. & $\begin{array}{l}\text { 3. Perawat menggunakan bahasa yang ramah dan } \\
\text { sopan }\end{array}$ & 7 & 3,69 & 0,511 \\
\hline & $\begin{array}{l}\text { 4. Perawat menggunakan bahasa yang jelas dan } \\
\text { mudah dimengerti }\end{array}$ & 4 & 3,89 & 0,318 \\
\hline & $\begin{array}{l}\text { 5. Perawat menjelaskan terlebih dahulu tindakan } \\
\text { yang diberikan }\end{array}$ & 5 & 3,86 & 0,363 \\
\hline 6. & $\begin{array}{l}\text { 6. Perawat memperkenalkan perawat yang } \\
\text { bertugas selanjutnya }\end{array}$ & 14 & 3,20 & 1,188 \\
\hline \multicolumn{5}{|c|}{$\begin{array}{l}\text { c. Peningkatan Keamanan Obat yang Perlu } \\
\text { Diwaspadai }\end{array}$} \\
\hline & $\begin{array}{l}\text { 7. Perawat mengidentifikasi gelang sebelum } \\
\text { memberikan obat }\end{array}$ & 3 & 3,89 & 0,381 \\
\hline 8 . & $\begin{array}{l}\text { 8. Perawat menjelaskan cara meminum obat, } \\
\text { waktu, dosisnya dan efek samping obat }\end{array}$ & 9 & 3,54 & 0,734 \\
\hline \multicolumn{5}{|c|}{$\begin{array}{l}\text { Kepastian Tepat Lokasi, Tepat Prosedur, Tepat } \\
\text { Pasien Operasi }\end{array}$} \\
\hline & $\begin{array}{l}\text { 9. Perawat mengidentifikasi pasien sebelum } \\
\text { melakukan operasi }\end{array}$ & 2 & 3,89 & 0,439 \\
\hline & $\begin{array}{l}\text { 10. Perawat menjelaskan operasi apa yang akan } \\
\text { dilakukan }\end{array}$ & 6 & 3,74 & 0,603 \\
\hline & $\begin{array}{l}\text { 11. Perawat memberikan lembar persetujuan } \\
\text { sebelum melakukan tindakan operasi }\end{array}$ & 1 & 3,90 & 0,428 \\
\hline \multirow{3}{*}{$\begin{array}{l}\boldsymbol{P} \\
\boldsymbol{K} \\
1 \\
1 .\end{array}$} & $\begin{array}{l}\text { Pengurangan Risiko Infeksi Terkait Pelayanan } \\
\text { Kesehatan }\end{array}$ & & & \\
\hline & $\begin{array}{l}\text { 12. Perawat menerapkan program kebersihan yang } \\
\text { efektif }\end{array}$ & 15 & 3,18 & 0,901 \\
\hline & $\begin{array}{l}\text { 13. Perawat menggunakan sarung tangan apabila } \\
\text { melakukan tindakan }\end{array}$ & 8 & 3,69 & 0,523 \\
\hline \multirow[t]{4}{*}{$f$} & Pengurangan Risiko Pasien Jatuh & & & \\
\hline & $\begin{array}{l}\text { 14. Perawat menerapkan langkah-langkah untuk } \\
\text { mengurangi resiko jatuh }\end{array}$ & 12 & 3,45 & 0,903 \\
\hline & 15. Perawat memasang pengaman tempat tidur & 10 & 3,48 & 0,863 \\
\hline & $\begin{array}{l}\text { 16. Perawat memberikan informasi terkait resiko } \\
\text { jatuh }\end{array}$ & 11 & 3,46 & 0,883 \\
\hline
\end{tabular}

Dilain sisi, didapatkan juga hal memperkenalkan diri (mean, 2,42 penerapan patient safety yang paling range 4). Poin ini tentunya diharapkan bisa kurang dilakukan perawat adalah dalam lebih tinggi, menginat indikator patient 
safety yang utama adalah ketepatan dalam identifikasi pasien dan komunikasi efektif)

\section{PEMBAHASAN}

Patient safety adalah merupakan suatu variabel untuk mengukur dan mengevaluasi kualitas pelayanan keperawatan yang berdampak terhadap pelayanan kesehatan. Dari hasil penelitian pada tabel 1 menunjukkan 104 orang $(62 \%)$ responden menyatakan bahwa pelayanan keperawatan sudah baik. Sedangkan 63 orang responden yang dengan hasil (38\%) menyatakan bahwa pelayanan keperawatan kurang baik.

Keselamatan pasien rumah sakit adalah suatu sistem dimana rumah sakit membuat asuhan pasien lebih aman yang meliputi assesmen risiko, identifikasi, dan pengelolaan hal yang berhubungan dengan risiko pasien, pelaporan,dan analisis kejadian, kemampuan belajar dari kejadian dan tindak lanjutnya serta implementasi solusi untuk meminimalkan timbulnya risiko dan mencegah terjadinya cedera yang disebabkan oleh kesalahan akibat melaksanakan suatu tindakan atau tidak mengambil tindakan yang seharusnya diambil (PerMenKes RI No. 1691/MenKes/Per/VIII/2011 tentang keselamatan pasien rumah sakit).

Program keselamatan pasien adalah suatu usaha untuk menurunkan angka Kejadian Tidak Diharapkan (KTD) yang sering terjadi pada pasien selama dirawat di rumah sakit sehingga sangat merugikan baik pasien itu sendiri maupun pihak rumah sakit. KTD bisa disebabkan oleh berbagai faktor, antara lain : beban kerja perawat yang tinggi, alur komunikasi yang kurang tepat, penggunaan sarana kurang tepat dan sebagainya (Nursalam, 2014). Secara keseluruhan program patient safety sudah diterapkan, namun masalah dilapangan merujuk pada konsep patient safety, karena walaupun sudah pernah mengikuti sosialisasi, tetapi masih ada pasien cidera, resiko jatuh, resiko salah pengobatan, pendelegasian yang tidak akurat saat oforan pasien yang mengakibatkan keselamatan pasien menjadi kurang maksimal (Bawelle et al., 2013).

Meningkatkan keselamatan pasien membutuhkan suatu standar pelayanan yang bermutu mengacu kepada standar tersebut telah dibuat dalam JCI (2011). Keseluruhan standar JCI setelah diidentifikasi, maka diperoleh standar yang paling relevan digunakan dalam mengkaji keselamatan pasien yang terkait dengan mutu pelayanan sesuai dengan JCI adalah sasaran internasional keselamatan pasien (SIKP) rumah sakit meliputi indikator : (1) ketepatan identifikasi pasien, peningkatan komunikasi yang efektif, (3) peningkatan keamanan obat yang perlu diwaspadai, (4) kepastian tepat lokasi tepat prosedur, tepat pasien operasi, (5) pengurangan risiko infeksi terkait pelayanan kesehatan dan (6) pengurangan risiko pasien jatuh. Standar pelayanan yang bermutu akan berdampak kepada penilaian konsumen.

Perawat harus melibatkan kognitif, afektif dan tindakan yang mengutamakan keselamatan pasien. Keselamatan pasien merupakan masalah kesehatan masyarakat global yang serius. Di Eropa pasien dengan resiko infeksi $83,5 \%$ dan bukti kesalahan medis menunjukkan 50-72,3\%. Di kumpulkan angka-angka penelitian rumah sakit di berbagai Negara, ditemukan KTD dengan rentang 3,2 - 16,6 \% (WHO, 2014 ; (Lombogia, 2016).

Hasil penelitian (Lombogia, 2016) yang menunjukkan bahwa kemampuan perawat dalam melaksanakan patient 
safety tentang mengidentifikasi pasien yang baik sebanyak 18 orang dengan hasil $(58,1 \%)$ sedangkan kurang baik sebanyak 13 orang dengan hasil (41,9\%). Hasil penelitian (Alfiah, 2016) yang menunjukkan bahwa kemampuan perawat dalam melaksanakan patient safety tentang komunikasi yang efektif dengan kategori tercapai penuh yaitu sebanyak 68 responden dengan presentase (100\%) sedangkan kategori tercapai sebagian dan titik tercapai yaitu $(0 \%)$.

Hasil penelitian (Kartika \& Melani, 2017) yang menunjukkan bahwa kemampuan perawat dalam melaksanakan patient safety tentang pemberian obat yang baik sebanyak 15 orang dengan hasil (50\%) sedangkan yang kurang baik sebanyak 15 orang dengan hasil (50\%). Hasil penelitian (Lombogia, 2016) yang menunjukkan bahwa kemampuan perawat dalam melaksanakan patient safety tentang pengurangan resiko infeksi yang baik sebanyak 21 orang dengan hasil $(67,7 \%)$ sedangkan yang kurang baik sebanyak 10 orang dengan hasil (32,3\%).

Hasil penelitian (Lombogia, 2016) yang menunjukkan bahwa kemampuan perawat dalam melaksanakan patient safety tentang kepastian tepat lokasi, prosedur, dan pasien operasi yang diterapkan sebanyak 27 responden dengan hasil (40\%) sedangkan tidak diterapkan sebanyak 30 responden dengan hasil (44\%). Selain itu, kemampuan perawat dalam melaksanakan patient safety tentang pengurangan resiko pasien jatuh yang baik sebanyak 16 orang dengan hasil $(51,6 \%)$ sedangkan yang kurang baik sebanyak 15 orang dengan hasil $(48,4 \%)$.

Dalam penelitiannya, (Bawelle et al., 2013) menyimpulkan bahwa ada hubungan pengetahuan perawat dengan pelaksanaan keselamatan pasien (patient safety) di Ruang Rawat Inap RSUD Liun Kendage Tahuna, $\mathrm{p}=0,014 \quad(\mathrm{a}<0,05)$. Penelitian ini sejalan dengan penelitian (Pujilestari dkk, 2013) yang menunjukkan dari 75 orang responden 38 responden $(50,7 \%)$ termasuk dalam kategori budaya keselamatan pasien tinggi. Dari 37 responden yang termasuk dalam kategori budaya keselamatan pasien yang rendah terdapat 23 perawat $(62,2 \%)$ dengan pelaksanaan pelayanan yang kurang baik dan 14 perawat $(37,8 \%)$ dengan pelaksanaan pelayanan yang baik. Sementara 38 responden dengan budaya keselamatan pasien yang tinggi seluruhnya $(100 \%)$.

Dari hasil penelitian, pelaksanaan patient safety oleh perawat belum sesuai dengan standar JCI. Dalam melakukan identifikasi pasien, perawat sudah melakukan identifikasi pasien dan memilah pasien, namun belum optimal dilaksanakan. Sedangkan dari segi komunikasi tampak efektif sesuai dengan standar JCI, ada komunikasi yang tepat, akurat dan efektif antara perawat, dokter dan pasien.

Dalam pengurangan resiko infeksi belum sesuai dengan standar JCI seperti pada saat melakukan tindakan perawat tidak menggunakan handscoon (sarung tangan) dan membiarkan luka terbuka lama. Dan pengurangan resiko pasien jatuh belum sepenuhnya dilakukan. Ini ditandai dengan tidak semua pasien dipasang pengaman pada brankar. Ini akan berakibat pada pelayanan yang kurang baik dan menimbulkan kurangnya kepuasan pasien.

\section{KESIMPULAN}

Konsep kajian tentang keselamatan pasien yang dilakukan pada penelitian ini mengacu kepada aspek kesehatan dan keselamatan kerja yang terkait dengan 
standar akreditasi yang dikeluarkan oleh Joint Commission International Accreditation Standards for Hospitals, 4th Edition (2011) serta serta dihubungkan dengan mutu pelayanan adalah aspek pelayanan di IGD rumah sakit, yaitu sasaran keselamatan pasien meliputi indikator : (1) ketepatan identifikasi pasien, (2) peningkatan komunikasi yang efektif, (3) peningkatan keamanan obat yang perlu diwaspadai, (4) kepastian tepat lokasi tepat prosedur, tepat pasien operasi, (5) pengurangan risiko infeksi terkait pelayanan kesehatan dan (6) pengurangan risiko pasien jatuh. Standar pelayanan yang bermutu akan berdampak kepada penilaian konsumen.

Berdasarkan hasil penelitian dapat disimpulkan bahwa penerapan patient safety oleh perawat di ruang bedah yang paling baik dilakukan adalah dalam hal memberikan lembar persetujuan sebelum melakukan tindakan operasi dengan mean 3,90 (range 4), dimana hal ini penting dilakukan sebagai bentuk inform concent bagi pasien. Diharapkan rumah sakit dapat mempertimbangkan manajemen penerapan patient safety sebagai rujukan sehingga perawat dapat bekerja secara optimal.

\section{UCAPAN TERIMA KASIH}

Terima kasih diucapkan kepada LPPM STIKes Fort De Kock yang telah memfasilitasi penelitian ini. Selanjutnya, terima kasih juga dihaturkan kepada seluruh responden atas partisipasinya dalam terlaksananya penelitian ini.

\section{DAFTAR PUSTAKA}

Alfiah, Nurhidayah. 2016. "Gambaran Penerapan Sasaran Keselamatan Pasien Oleh Perawat Pelaksana Di Unit Rawat Inap RSUD Haji Padjonga Daeng Ngalle Kabupaten
Takalar”. (Skripsi). Makasar : Fakultas Kedokteran Dan Ilmu Kesehatan, Universitas Islam Negeri (UIN) Makasar.

Andriani, Aida. 2017. "Hubungan Mutu Pelayanan Kesehatan Dengan Kepuasan Pasien Diruangan Poli Umum Puskesmas Bukittinggi”. Journal Endurance 2 (1) February 2017 (45-52).

Bawelle, S. C., Sinolungan, J., \& Hamel, R. S. (2013). HUBUNGAN PENGETAHUAN DAN SIKAP PERAWAT DENGAN PELAKSANAAAN KESELAMATAN PASIEN. Ejournal Keperawatan (e-Kp), 1(1), $1-7$.

Gunawan, Widodo, F. Y., \& Harijanto, T. (2015). Analisis Rendahnya Laporan Insiden Keselamatan Pasien di Rumah Sakit An Analysis of Low Adverse Error Reporting at Hospital. Jurnal Kedokteran Brawijaya, 28(2), 206-213. Retrieved from jkb.ub.ac.id/index.php/jkb/article/do wnload/962/479

Iswati. 2013. "Penerapan Sasaran Keselamatan Pasien Di Rumah Sakit". E-journal Keperawatan (EKp) Vol. 2 No. 2, Juni 2013.

Kartika, I. R., Hariyati, R. T. S., \& Nelwati. (2018). Kompetensi Perawat Dan Kepuasan Pasien Terhadap Pelayanan Keperawatan di Rawat Jalan. NERS : Jurnal Keperawatan, 14(2), 46-54.

Kartika, I. R., \& Melani, V. (2017). APPLICATION OF ,, SIX RIGHTS " ON MEDICATION ADMINISTRATION BY NURSE AND PATIENT SATISFACTION. Jurnal INJEC, 2(2), 178-183.

KemenKes, RI. 2011. Peraturan Menteri Kesehatan RI No. 1691/MenKes/Per/VIII/2011

Tentang Keselamatan Pasien Di Rumah Sakit. Jakarta. Lombogia, A. (2016). Hubungan Perilaku 
Dengan Kemampuan Perawat Dalam Melaksanakan Keselamatan Pasien (patient safety) di Ruang Akut Instalasi Gawat Darurat RSUP Prof. Dr. R. D. Kandou Manado. EJournal Keperawatan (e-Kp), 4(2), $1-8$.

Mudayana, A. A. (2014). PERAN ASPEK ETIKA TENAGA MEDIS DALAM PENERAPAN BUDAYA KESELAMATAN PASIEN DI RUMAH SAKIT. Supplemen
Majalah Kedokteran Andalas, 37(1), 69-74.

Nursalam. (2014). Manajemen Keperawatan : Aplikasi dalam Praktik Keperawatan Profesional. Edisi 3 dan Edisi 4. Jakarta : Salemba Medika

Triwibowo, Cecep. (2013). Manajemen Keperawatan di Rumah Sakit. Jakarta: Trans Info Media. 